\title{
Modernity: A Way of Urbanism -- Banaras in Indigenous Trans-Formations
}

\author{
ANIMESH DEV \\ Architect and Urban Designer, 203/204, D-block, Shyamali Colony, Doranda, Ranchi, \\ Jharkhand 834002 India
}

\section{E-mail: devanimeshdev@gmail.com}

Received: October 18, 2015I Revised: December 14, 2015I Accepted: January 08, 2016

Published online: July 4, 2016

The Author(s) 2016. This article is published with open access at www.chitkara.edu.in/publications

\begin{abstract}
:
Tradition of tomorrow is the modernity of today and

Today's tradition was the modernity of yesterday.

Modernity, as a process and not as an output, is a derivative of transformation. Transformations are different for diverse aspirations of its producers. Aspirations are negotiations between the needs and desires, and what can actually be achieved. Traditional beliefs and practices coexist, transform and sometimes depart from the original, as a result of aspirations of modernization and inspirations from the idea of modernity, to become modern.
\end{abstract}

Since, a traditional urban community is deeply grounded in native tradition while becoming globally modern, an enquiry about how we are changing internally will lead us to the process of how we interpret and change modernity, thereby exploring various indigenous ways of becoming modern. Indigenous Modernity varies with different contexts and is a harmonious adaptation to contextual contemporary life. The cause for such transformations can be global but the effects will always be a derivative of indigenous reactions to modernity.

In the city of Varanasi, the agents of modernity are spread across different periods, transforming the economic, social, and built fabric of the city. One can stretch the strands of transformations from the sacred core of the city (transformative layer of modernity, Kashi), to the outer periphery of the core (additive layer of modernity, Varanasi) and, sometimes to the trans-urban areas that grapple with global aspirations and new economic opportunities.

This paper is based on a research aimed at discovering the transformations that have occurred under the forces of modernization within the physical fabric of Varanasi as well as within its society. Further, the study also looks at how sacred cities, the identity and intrinsic value of which are grounded in unassailable tradition, derive their 'indigenous modernity' to create a unique urbanism. An understanding will,

Creative Space (CS)

Vol-4, No-1

July 2016

pp. 1-28

CHITKARA 司

(C)2014 by Chitkara

University. All Rights

Reserved. 
thus, be made on modernity as something both deeply traditional and being constantly reinvented through contemporary practices and of the significant link between modernity and transformation as a key to understand the phenomenon of 'indigenous modernity'. The study spans from typological level, to the Mohalla level and, to the city level, and finally recommends ways of sustainable indigenous modernization.

Keywords: Indigenous Modernity, Social Anthropology, Transforming Traditions, Urban Transformations, Urban Design Recommendations.

\section{MODERNITY AND THE MODERN}

Modernization is a form of development in which systems such as 'value', 'society' and, 'personality' are interwoven in such a way that universalisticsecularistic positive values make differentiations within the status-role system and evolve a social personality. Modernity, from the point of view of individual, is a state of personality trait-scientific worldview. Modernity, from the point of view of a given society as a whole, is a judgment on its level of development in material and ideational aspects.

\subsection{Modernization and Tradition: The Timelessness of Modernity}

Beginning from the undocumented period, the society that then existed is today regarded as 'traditional'. As the time proceeds, the winds of change, which are the internal aspirations and external influences, help city and its society to evolve. This change is 'modern'. At any particular frame of time, both 'traditional' and 'modern' co-exist. This co-existence (which is always in a flux) is the 'transformation' and defines the degree of adaptability in a society as well as the corresponding spatial arrangements of the city. As time proceeds, this fusion of modern and the-then-traditional become traditional for the future and again the forces of change, the aspirations and influences again help the city to evolve further. Again, both co-exist and this process becomes the timelessness of modernity. The present society, as an overlap of several modernities, testifies that modern is a relative term. And, now, one can think that the term 'undocumented period' is not as unstable as it was at the beginning of this paragraph (Fig. 1).

Implicit in such writings is the belief that tradition and modernity are bi-polar opposites. However, social processes are not so simple as to be accommodated in this dichotomy. Society is never completely modern or completely traditional, but always a substantial and desirable fusion of both. Tradition and modernization represent a continuous process. None of them, at the same time, can be regarded as a static phenomenon. Tradition cannot be completely identified with the past and modernity with the present. An 

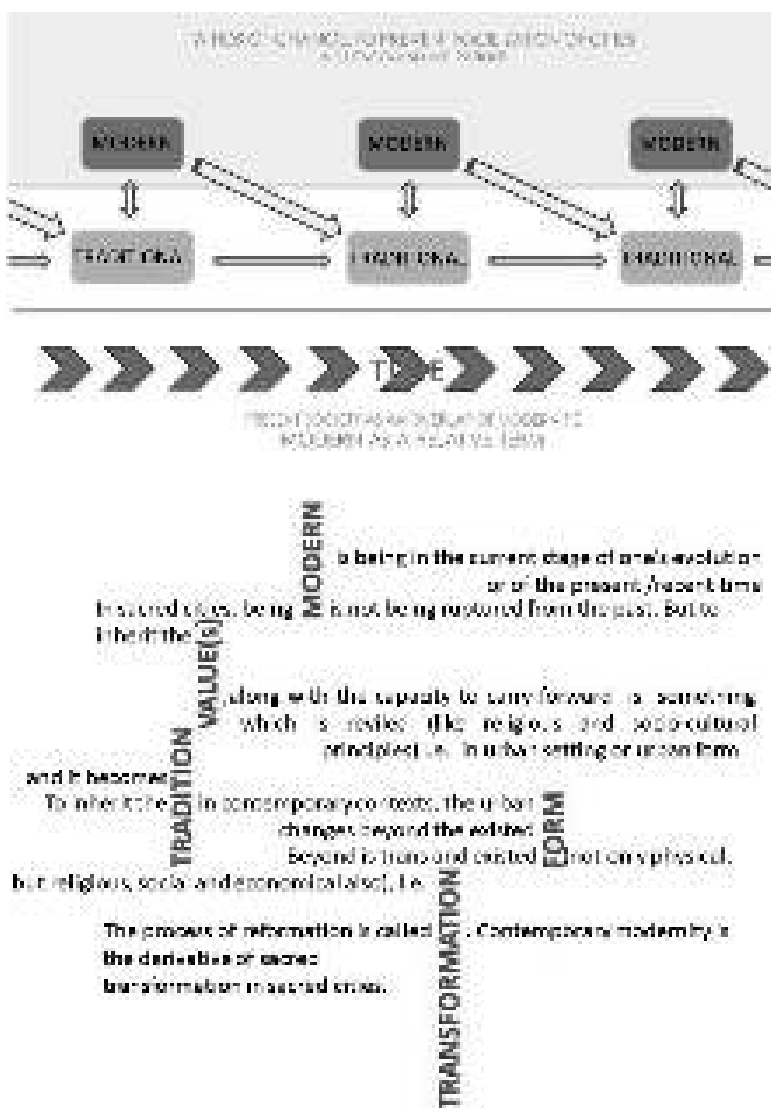

Modernity: A Way of Urbanism

-- Banaras In Indigenous Trans-

Formations

Figure 1: The Modern and the Traditional (Source: Author).

Figure 2: Modernity and Transformation (Source: Author).

element of modernity today can be enriched as a tradition tomorrow only if substantiated modernity becomes tradition and traditions practiced today become a part of modernity. Thus tradition and modernity are different moments of a continuous process. A final question, which arises about modernization, is that of its relationship with tradition. How far will modernization succeed in an integrated development? How far will tradition maintain its identity in the wake of forces of modernization? Also, there are societies that traditionalize innovation and, thus, adapt the process of modernization (Fig. 2).

\subsection{Indigenous Modernity: Conceiving Modernization}

The differences are clear; some say modernity comes unambiguously from Europe; some say we have never been modern, that modernity is a fiction imposed on the world by powerful actors seeking to dominate others; and 
Dev, A
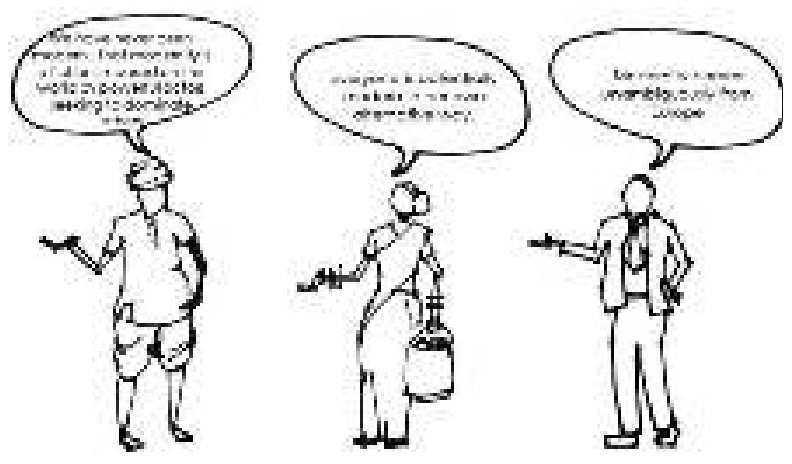

Figure 3: Modernity and its perception (Source: Author).

others say that everyone is potentially modern in their own alternative ways (Fig. 3). It is safe to say that modernity is now understood as neither fixed nor singular, and that it can only be understood in relation to specific social and economic contexts. While we all are modern, we all do not necessarily think that being modern is good. A modernist is someone who thinks that being modern is good. So likewise, modernism is the belief or ideology that proclaims modernity as good. The contribution of urban design in this field is often to reveal the diverse and specific cultural identities in unified globalization, leading to the notion of multiple indigenous modernities.

\section{MODERNIZING BANARAS}

\subsection{Agents of Modernity: The Cause and Effect}

The ancient city of Varanasi was not built in a day. Being one of the holiest cities of Hinduism, the impact of the religion is found everywhere in the city in the chanting bells and the monotonous but oddly soothing Sanskrit hymns, in the fragrant flower offerings, and the coloured powders (which decorate the foreheads of the devout), sold in a myriad roadside shops in millions of worshippers and the thousands who offer their salvation or services in the holy waters of River Ganga. Since ancient times, the many parts of the natural and cultural landscape of the city have played an active social role in nurturing a contemporary society that is closely associated with the traditional way of life. The city is a place of pilgrimage and a holy site for sacred baths in the River Ganga, to have a good death, to get relief from transmigration, to learn and receive spiritual merits, etc.. Despite several downfalls and upheavals, the city has still maintained its sacred spirit and its traditions are fully alive even today. 

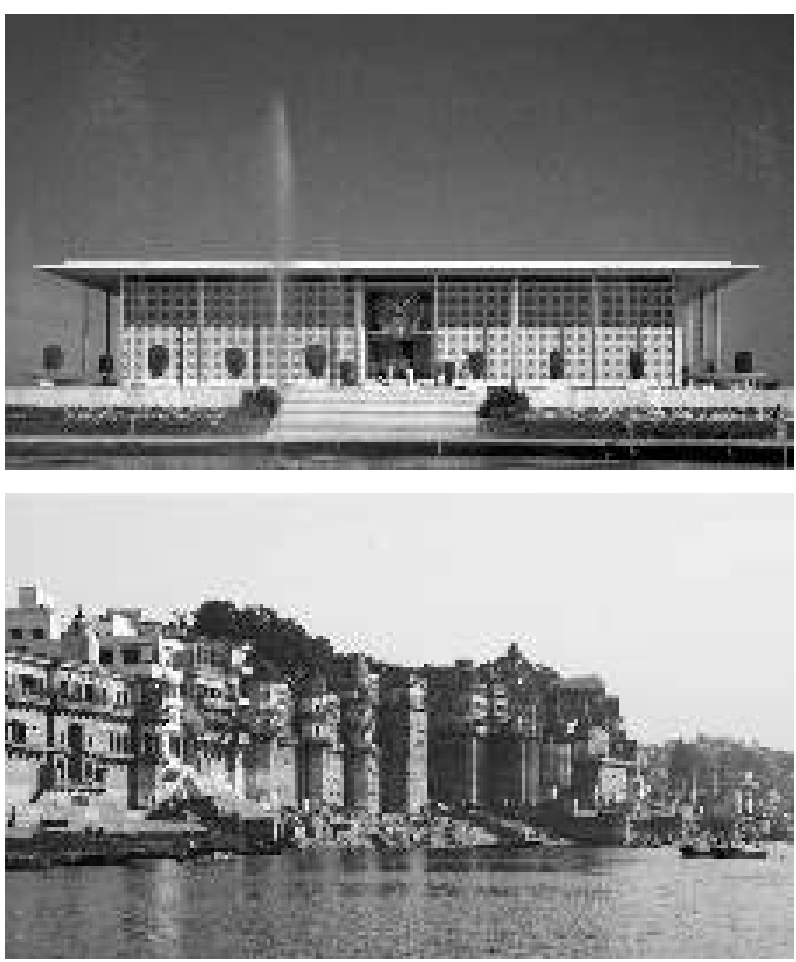

Modernity: A

Way of Urbanism

-- Banaras In

Indigenous Trans-

Formations

Figure 4: Representation of American Embassy, Delhi (Source: huffingtonpost.com).

Figure 5: Ghats of Banaras (Source: en.wikipedia.org).

The urban character of Banaras is very complex. The traditional city of Varanasi, Kashi, has undergone transformations over time while still holding on to its original character and ethos. Areas of the old city exhibit dense development due to their proximity to the holy Ghats, and also as a result of their social and economic value and their longevity of existence. This core, the Pakka Mohalla, represents the cultural fabric of the city. Cities are representation of layers of modernity, a modernity which is experienced at different times is summarized to the present condition. The agents of modernity, which are the key triggers of development became pivotal to modernity, impacting the contemporary urbanism of the city. Discussed below are some cause-and-effect relations in the city of Banaras

\subsubsection{Claims over the City}

Idea: To plant a seed representing one's province in the city's core that is wealthy, high in cultural values, religious significance and identity (Fig. 4).

Realization of the Idea: Construction of Mahals or Havelis and Ghats as a representative expression of the concerned province (Fig. 5). Creating the 
Dev, A
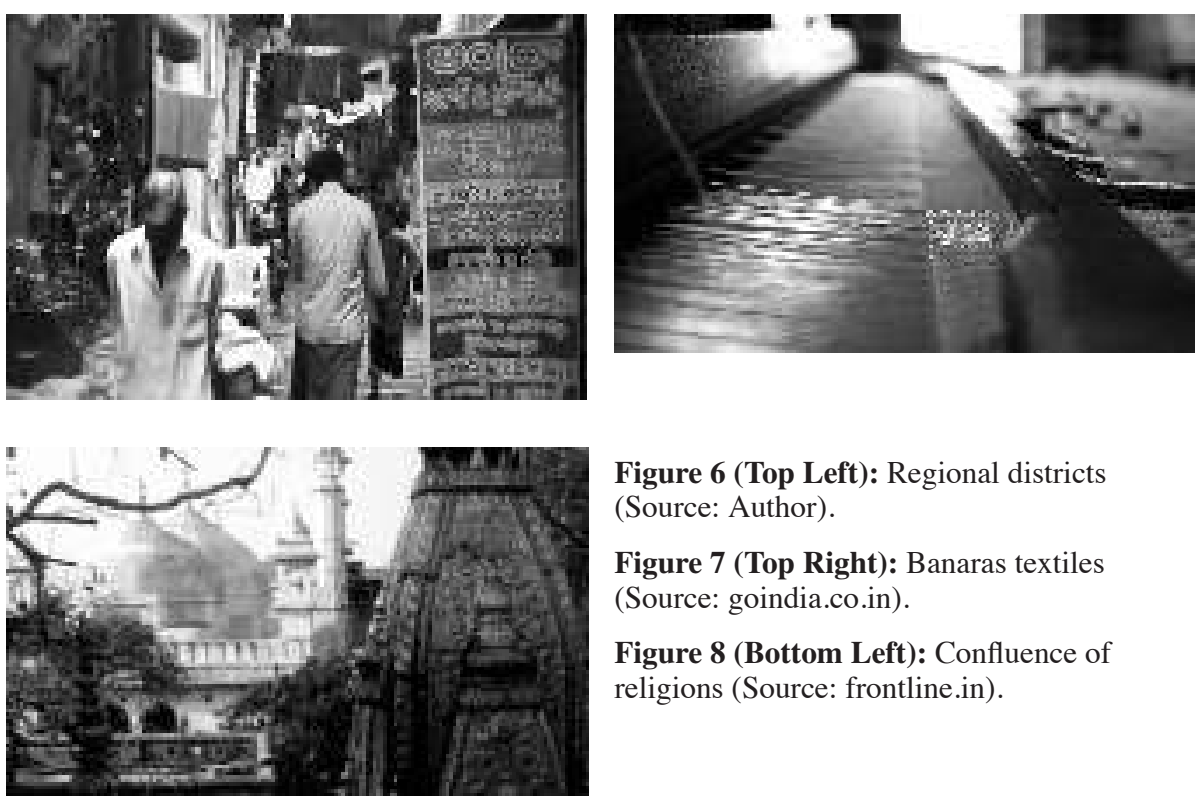

Figure 6 (Top Left): Regional districts (Source: Author).

Figure 7 (Top Right): Banaras textiles (Source: goindia.co.in).

Figure 8 (Bottom Left): Confluence of religions (Source: frontline.in).

required impact during the development of the Pakka Mohalla or the Core City Effect: Even today, the districts behind such edifices are largely utilised by the same or similar ethnic and cultural groups. Examples: Mysore Ghat, Raja Vizianagram Ghat, Rana Ghat, Darbhanga Ghat, Tripura Bhairvi Ghat and Baji Rao Ghat. Thus, multi-culturalism became pivotal to Modernity (Fig. $6)$.

\subsubsection{City of Trade}

Idea: Exploit cultural, ideological and natural resources of Banaras (Fig. 7). Realization of the Idea: Construction of bridges, highways, trading nodes, manufacturing units and other infrastructure in the city.

Effect: Today, the new part of Varanasi is an 'additive layer' of modernity and the older part, the core of the city is a 'transformative layer' of modernity. Modernity here, is described as a new role of the city with new urban forms.

\subsubsection{Religious and Social Contestations}

Idea: To enhance the impact of Islam (established by construction of a mosque like the Gyanvapi Mosque) as a policy of power.

Realization of the Idea: The successive contestations by Mughals on sacred nodes like temples and Ghats. (Fig. 8) 
Modernity: A

Way of Urbanism

-- Banaras In

Indigenous Trans-

Formations

Figure 9: Malls as the new landmarks (Source: Google imagery).

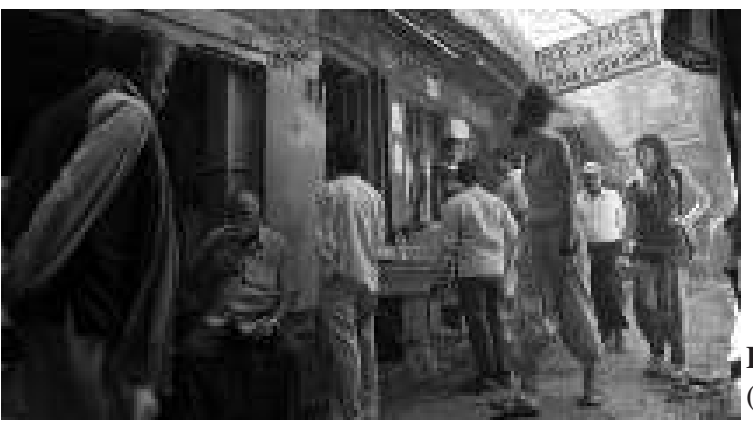

Figure 10: The Blue Lassi Shop (Source: eltonyoga.com).

Effect: It acted contrarily over the beliefs of Hindus by the need to strengthen their religiosity, the realization of the presence of 'others', led to an enhancement (rather than a dilution) of self-solidity.

\subsubsection{Planning and Infrastructure}

Idea: To implement planning schemes based on the western ideology, which can co-exist with the existing city form.

Realization of the Idea: The Master Plan became the process to implement the Idea and generated better conditions for agents of modernity to act.

Effect: Similar building bye-laws were applied to both parts of the city, which affected the spatial and form-based unit of the traditional neighborhood. Is the Local Area Plan, a form of indigenous contextual modernity?

\subsubsection{Leisure of Society}

Idea: To become like others considered modern; resembling the image of modernity. 
Realization of the Idea: Construction of elements of modernity, such as shopping malls, cinemas, modernization of markets in terms of variety and appearance. This becomes a trigger of spatial and functional changes (Fig. 9). Effect: One of the illustration of indigenous adaptive manifestation of cultural confluence is the multiple flavored "Blue Lassi" (Fig. 10), a small shop with Wi-Fi and air conditioning. Being located along the route for 'death processions', it has become a tourist attraction despite the heterotypic nature of the street.

\subsection{Characteristics of Banaras's Modernity}

The agents of modernity are the catalysts of transformation in the sacred fabric of Banaras. These catalysts, in turn, form the characteristics of modernity which can be seen in economic, social and physical fabric at three different scales. These scales are the Core City or the Pakka Mohalla Level, the Community or the Mohalla level, and the Individual Typological Level.

\subsubsection{The Core City or the Pakka Mohalla Level:}

Modernity in the Economic Fabric: The Core City area exhibits a diverse functional role which includes wholesale markets (Central Business District), the tourism district, and the religious center.

Modernity in the Social Fabric: Being a witness of contestations, the Pakka Mohalla has evolved into diverse religious and linguistic ethnicities.

Modernity in the Built Fabric: Due to differentiated characteristics of modernity and traditions, the Pakka Mohalla's homogeneous built fabric is continuously changing its imagebility (Fig. 11).

\subsubsection{The Community or the Mohalla Level:}

Modernity in the Economic Fabric: A marked transformation can be seen in original 'mixed-ness' of function and ethics of traditional communal economics. Modernity in the Social Fabric: Due to the economic forces, there are transformations with respect to social homogeneity, that is, clustering and then re-clustering of social groups both, within a generation and in the transgenerational shift (Fig. 12).

Modernity in the Built Fabric: At the community level, there is a change in formand-space relationship, which corresponds to visual and physical relationships.

\subsubsection{The Typology or Individual Stories of Transformation:}

Modernity in the Economic Fabric: Changing professions lead to de-sacralisation and, hence, change in the social structure of the fabric.

Modernity in the Social Fabric: Change in the number of families, household size, ethnicity and social structure brings transformation of the social fabric. 


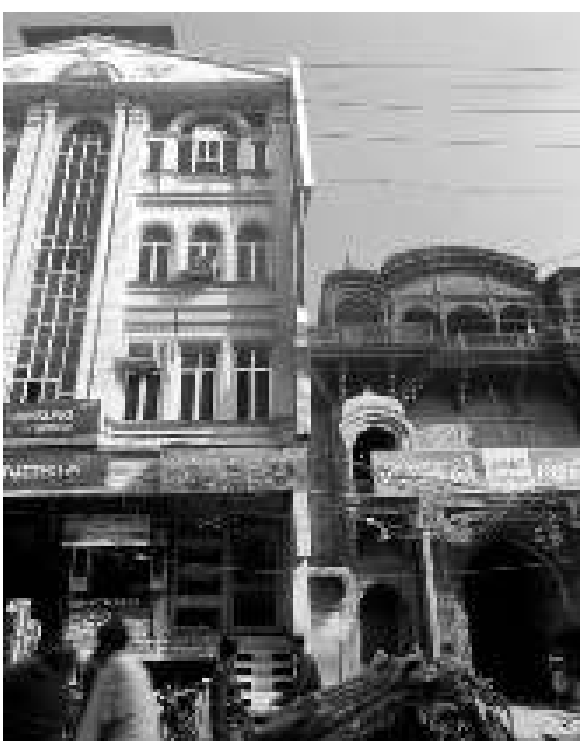

Figure 11: The Modern at different times (Source: Author).

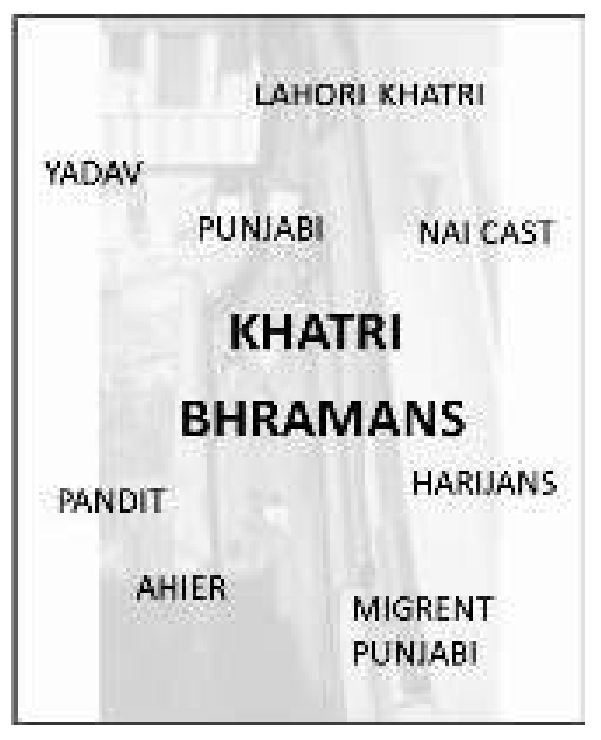

Figure 12: Social clustering (Source: Author).

With multi-nuclear families replacing the joint family, one can also witness the evolution of new typologies.

Modernity in the Built Fabric: Transformation in the housing typologies can be seen from high-rise with basements to detached housing.

\subsection{Urban Design Based Understanding of Evolution}

\subsubsection{Physical Permeability and Visual Porosity}

Economic Cause: Wholesale and Retail Activity in the Core City

Effects: Morphological Transformation: Because of the high residential density and economic pressures, the ground floors of the residential units in a neighborhood are made more accessible. This eventually results in an overall increase in the publicly accessible commercial fronts. In many cases, the new economic forces coupled with the redundant condition of the original residential structures, have led to the development of commercial corridors that have with deeper rows of shops and godowns (Fig. 13).

Spatial Transformation: As the number of families residing in each typical traditional courtyard house has increased over time, the courtyard which was the private open space of one family, has been transformed into a semi-private open space shared by several families. The character of a community's gali (street) is 
Dev, A
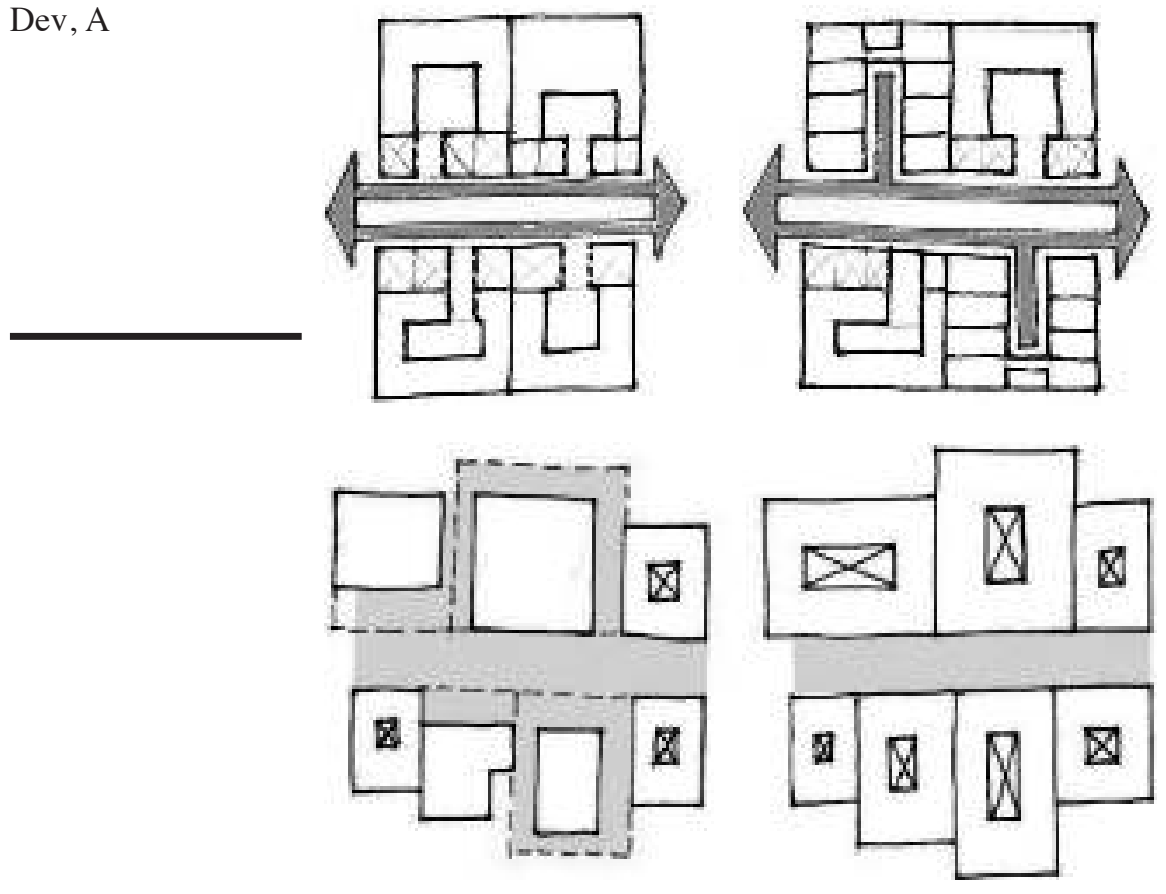

Figure 13: Physical Permeability (Source: Author).

Figure 14: Setbacks and new spaces (Source: Author).

now transformed to that of a Commercial Street with a larger number of strangers as vendors, buyers and tourists. The overall visual porosity at ground level is increased to benefit the economy. Segregation of the public and the private space now happens vertically segregated in comparison to the earlier horizontal segregation in terms of the publicly active front and the private domestic rear.

\subsubsection{Building Regulations: Controlling the Built Form}

\section{Effects:}

Morphological Transformation: The prevailing, contemporary building regulations have caused a morphological change that largely affects the neighborhood and the core city. It impacts the fabric when a new construction is needed or desired to add to or replace parts of the exiting built environment (subject, of course, to appropriate judicial applications). For instance, the alterations in fabric, which are guided by the building byelaws, can be seen in new units that may be 'attached', 'semi detached' or 'detached' to in relation to the original as per the plot size.

Spatial Transformation: This also indirectly guides the formation of new open spaces between built forms. It contrasts with the typical urban grain of 'attached courtyard housing' and affects the relation of activities that require a 


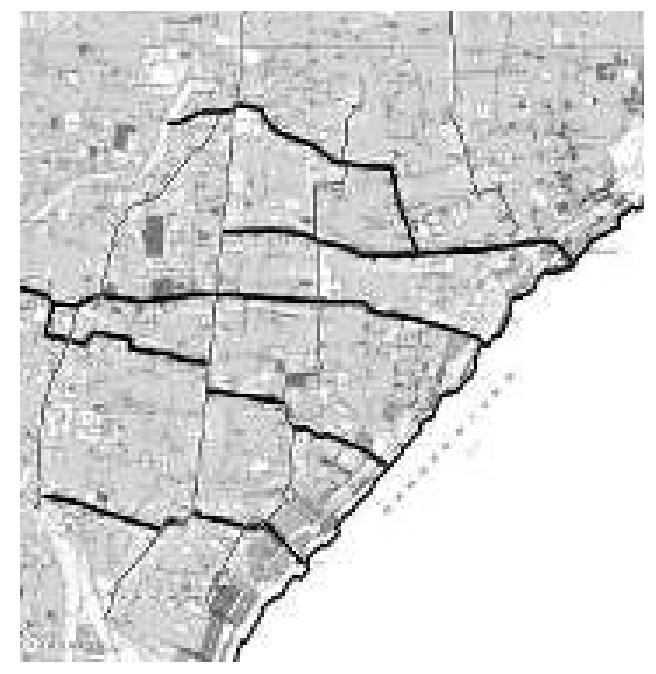

Figure 15 (Left): Parallel and perpendicular streets to river (Source: Author).

Figure 16 (Bottom): Map of the Mohalla near Dashashwmedha Ghat (Source: Urban Design Study, S.P.A., New Delhi).
Modernity: A Way of Urbanism

-- Banaras In Indigenous Trans-

Formations

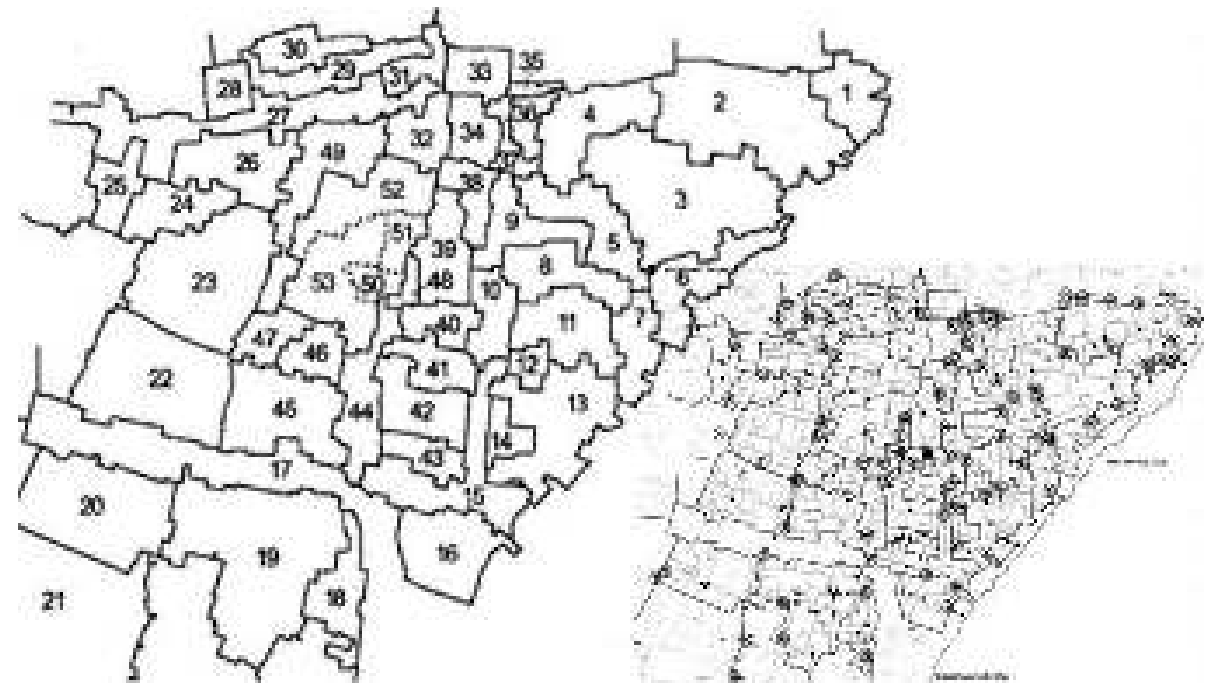

certain degree of privacy. Also, the emergence of such new types of spaces (as a result of 'setbacks' as well as merging and division of plots), in turn, gives rise to new negotiations in activities (Fig. 14).

Street Orientation and Porosity: Banaras lives through narrow lanes, some of which are oriented parallel to the river while some lead to it. Each possesses different porosity. For example, as the street leading to the river (or the perpendicular streets) facilitate direct access to the Ghats for visitors, pilgrims and the locals, these display a marked commercial character with heavy 
Dev, A

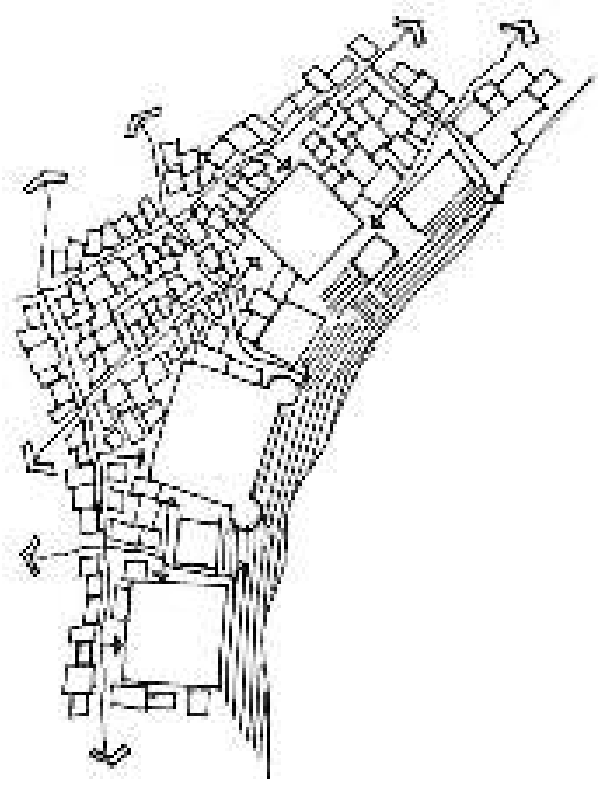

Figure 17: Structure of the Mohalla (Source: Author).

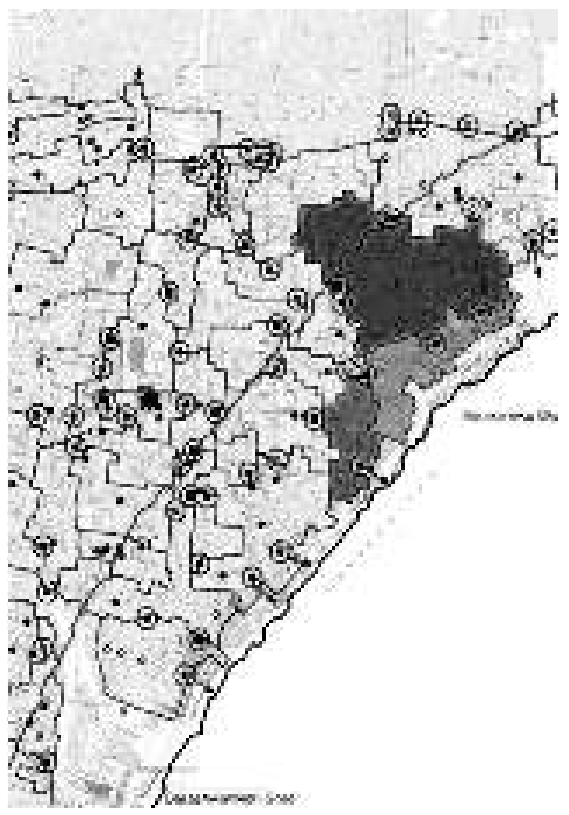

Figure 18: Mohalla and Core Heritage Zone (Source: Author).

incidence of hotels, guest-houses and, other touristic and pilgrimage-oriented building use. On the other hand, since the streets that are parallel to the river are predominantly used by the local residents, their residential character with small-scale local commerce, shrines and ashrams is marked (Fig 15).

\subsubsection{Transforming Grain and Texture, and the New Imageries}

Cause: Growth of the Residential Population

\section{Effects:}

Morphological Transformation: The 'fine grain and even texture' of the original city is in the process of being transformed into one resembling 'course grain and uneven texture'. It is the result of increasing densities, the natural population growth and, economic forces, which shift population from outside to inside the core (Fig. 16).

Spatial Transformation: Evolution of new imageries (such as a tall multistoreyed tower) and the masking of the old by the new (such as a temple hidden by new buildings around it) are some examples of spatial transformation.

Evolving Fabric: As mentioned earlier, construction of mahals, havelies and temples close to the river was undertaken to plant a province or region- 
based seed in the core of the city. Each such nucleus became an impetus and a centre for growth of similar provincial communities in adjacent areas and also resulted in construction of the continuous stretch of steps leading to the river (Fig. 17). The religious, social and professional association of several such communities cumulatively results in the unique culture of the Pakka Mohalla. However, as of now, the city is slowly getting polarized between the new non-sacred activities and the traditional sacred activities, even though each is gaining strength in its own realm. Tourism and pilgrimage, while altering tradition in a modern way, have also become the agents of continuation of the religious and cultural traits of the Pakka Mohalla.

Building Heights and Sights: In the economic fabric, other than real-estate, tourism plays an important role. The taller the building, the better is the view of the river. This is a significant cause for the changing urban texture.

\subsubsection{Transforming Functions and Re-shaping Activity Patterns}

Economic Cause: Tourism, Real Estate, Professions and Liberal Aspirations New layers of modernization, expressed through building controls and development guidelines, are manifested over the sacred fabric of Banaras. The prevalent social boundaries of communities are now overlaid by legal notifications such as "Core Heritage Zone Regulations" (Fig. 18).

\section{Effects}

Functional Transformation: The traditional work-live relationship, as an attribute of the built fabric represented the compatibility of residential, trade and manufacturing activities, and the integrated socio-economic system. Upgrading of the middle class living conditions of living and, the new economic scenario with respect to the rise of wholesale markets, real-estate values and tourism have become one of the parameters of change in form and function.

Economic System: The interdependency of Mohallas was high as the communities represented specialized professions or social function (such as silk weavers, utensil manufacturers, Pandits, widows, boatsmen samaj, etc.). But, in the socially transforming scenario and changing economics, the boundaries are diluting and the entire fabric becoming increasingly homogeneous.

Functional 'Mixed-ness': Keeping the business within the people of a community is the economic sacrality in the traditional socio-economic system of Banaras. The modern globalized/open business and aspiration does not respect the socio-economics in the community system. This transforms the functional character of a neighborhood and the level of mixed-ness or multi-functionality rises.
Modernity: A

Way of Urbanism

-- Banaras In

Indigenous Trans-

Formations 
Dev, A
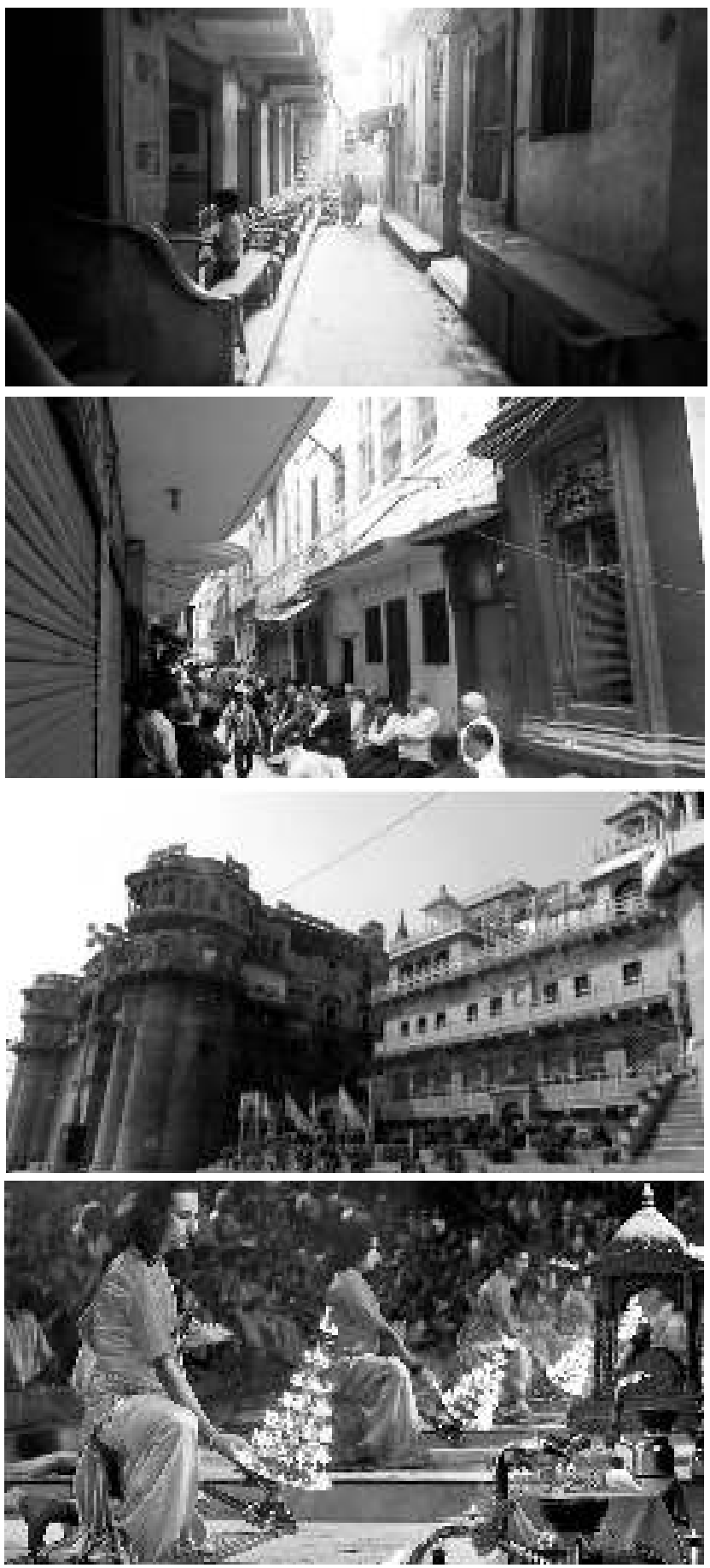

Figure 19: Streets of the Mohalla (Source: Author).

Figure 20: Condolence Ceremony on the street (Source: Author).

Figure 21: New economic models as contested spaces (Source: Author)

Figure 22: Modern religiosity (Source: theholidayindia.com). 
Activity Transformation: The extent of change is least in the sacred-oriented communities. But, transformations can be seen in the traditionally sacred pattern of taking the daily morning baths on the Ghats by all members of the community. This is now happening within the individual residential units. In terms of events, there is also the example of 'condolence ceremonies' (Fig. 19), which used to be conducted in the courtyard of the house. These are now shifted to the public space of the street (Fig. 20) as the courtyard typologies have been transformed to mixed-use and semi-private space types. Also, the increase in density and number of people to be accommodated are now much higher and hence the activity needs to spread out.

Transformation in Social Fabric: Due to economic pressures and increasing aspirations of the residents, the communities are becoming socially homogenous. The original clustering which had happened during the formation of the social fabric is constantly getting re-grouped and evolving into a modern homogenous society. The clustering of religious and linguistic ethnicities (and now of international languages as well) still continues to influence the numerous identities embedded in Varanasi. The older activity patterns have been indigenously modified to create synergy with existing forces of modernization, with the building regulations: guiding the functions. Effects in Activity Transformations: As described above functional and social 'mixed-ness' changes daily. Community gatherings on streets have increased mainly because of the change in the definition of "common-unity".

\subsubsection{Organization of Open Spaces}

Other than Ghats, streets are the public spaces of the neighborhood. The definition of a street and a public space is mixed as the 'Ghat'is also a 'street' or a 'promenade' along the river on to which other internal lanes merge to present the view of River Ganga. The unique organization of spaces, where the streets interspersed with porticos or verandahs and chabutras, weave through neighborhoods and terminate at the highest order of the Varanasi's public open spaces, i.e., the Ghats. The spilling over of different kinds of activities (domestic, economic, recreation) along with widening and narrowing physical formations, develops the mixed-use purpose of these streets.

Hierarchy of Spaces: The spatial organization in Banaras presents a hierarchy in the order of their 'private' to 'public' character. Internal courtyards, chabutras along streets, community temples and, finally, the Ghats become integral component of this spatial order. Because of high religiosity, other than community temples, all forms of spaces are under transformation. Even the Ghats witness the contestation of public space by hotel owners (Fig. 21), and that of the smaller niches by sadhus and pandits.
Modernity: A Way of Urbanism

-- Banaras In Indigenous Trans-

Formations 
Activity Transformation: The footfall of tourists and pilgrims in these lanes, changing the orientation of commercial activities, from domestic and wholesale to globalized tourist oriented facilities (souvenirs, religious goods, lassi and local eateries) is unique to the Banaras way of life. The quality of robustness is enhanced by active building fronts, least vehicular interference, communal associations, and micro-climatically controlled building layouts. From 'death processional routes', traditionally following the boundaries of communities, to local pilgrims' circuits which follow the streets leading to community temples and, other significant symbols of religion such as a tree or cowsheds, the streets not only facilitate mobility but also the daily life activities.

One of the most iconic symbols of modernity in public space is the activity of aarti. The modern form of aarti is a tourist attraction sponsored by luxury hotels as an image of religiosity. It is more of a choreographed performance with traditionally dressed aarti performers. However, the monumentality associated with this act does create a feeling of belief in the masses (Fig. 22).

\subsubsection{Characteristics of Transforming Movement Networks}

On similar trajectories, the meandering lanes of Banaras still prevail as a pedestrian realm. Their twists and turns, widening and narrowing, changing enclosures, the steps and ramps contribute to their unique character. Steps are now getting associated with steep ramps for access of two wheelers to make connections with contemporary surroundings of the core city.

Economic Cause: Increasing affordability with longer work-live distances

\section{Effects}

Mobility Transformation: With the developing economic condition of people living in houses abutting these lanes, open areas located on the fringes have been converted to common parking grounds that are guarded by walls and gates. The residents pay hefty amounts for the use of such grounds while many have left the narrow fabric by mentioning it as one of the reasons. More predominantly, the use of two wheelers facilitates mobility between larger work-live distances, as the mode is much more compatible to the core city.

Socio-spatial Transformation: "The beeps are disturbing" as mentioned by one of the residents, because of which the old people of the neighborhood are being shifted to the rear interior spaces.

Restricting Pace of Transformation: The pace of transformation is being reduced as the bringing of raw materials from these lanes proves difficult, though there are other factors that accelerate the transformations. 

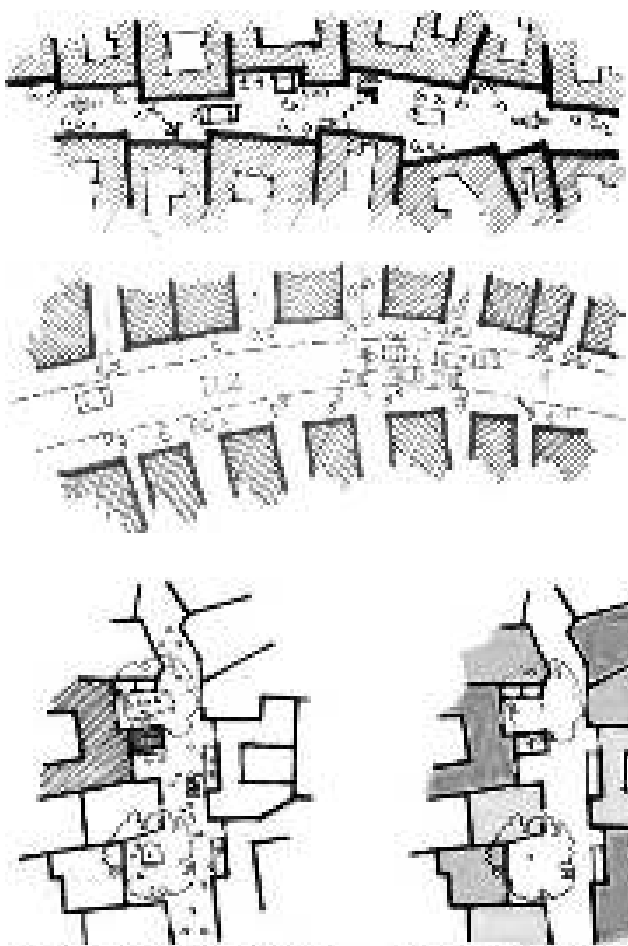

Pespe wo beong to teripls ine i- the remainty
Figure 23 (Left): Setbacks and street character (Source: Author).

Figure 24 (Below): Temple as property (Source: Author).
Modernity: A Way of Urbanism

-- Banaras In Indigenous Trans-

Formations

\section{MODERN TRANSFORMATION}

\subsection{Implications of Total Transformation}

A speculated scenario of total transformation: Given that these scenarios continue unchecked, what will be the resultant implications?

3.1.1. Under the prevailing building controls, all buildings will have setbacks from the road / street and no courtyard will exist. This will hamper the traditional microclimatic controls at typological level as well as Mohalla level, which then will require artifical and mechanical solutions rather than sustainable, indigenous methods of mitigation.

- This will transform the traditional character of narrow streets in Banaras. Also, issues of parking and strangeness in street will increase, which will further hinder the socializing opportunities which the existing street offers.

- Widened streets encourages motor vehicles to enter into the dense fabric and increases commercialization due to pre-existing wholesale activities and high tourist footfall (Fig. 23). 
Dev, A

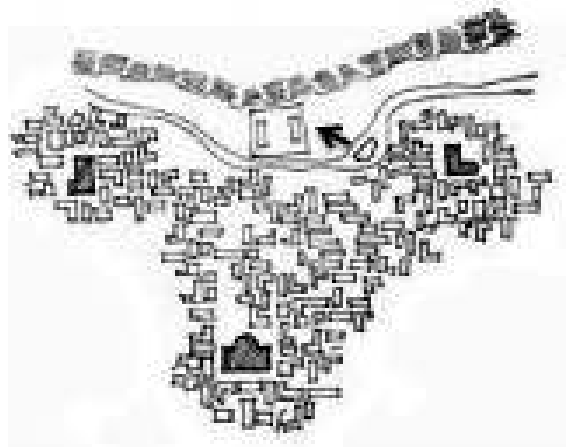

Establishment of vantage point near the communities

Figure 25: Economic Gentrification of Communities (Source: Author).

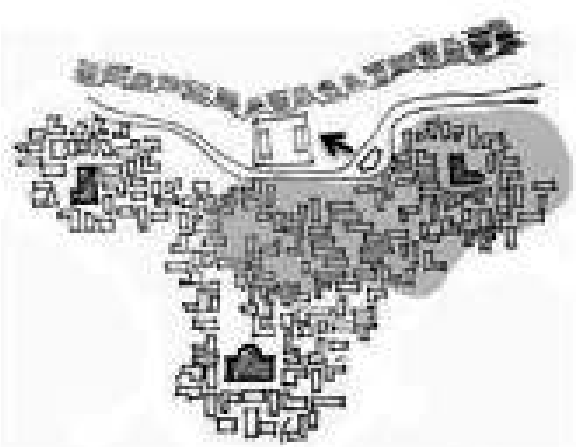

Displacement of communities due to economic forces

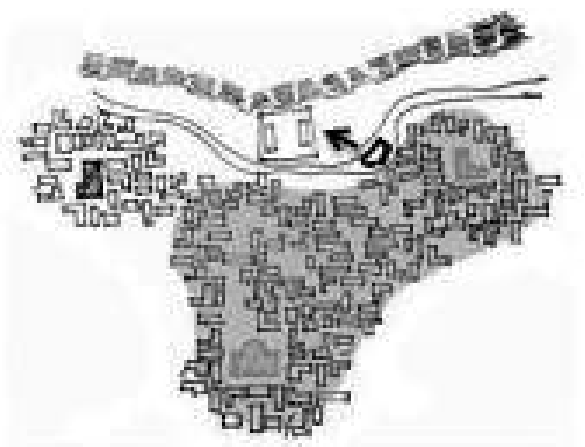

May lead to weakened mohalla generators and strengthened vantage point

3.1.2. The river-facing Ashrams, originally meant to accommodate pilgrims of a particular community, have now been transformed to offer "lifestyle of ashram" and the view of river to tourist. By solving both purposes of sacrality and tourism, this helps in globalizing local traditions. Also, by developing a new transformed typology for such sacred units, increases the possibility of traditions continuing to exist in the future without inversely affecting their sacrality.

3.1.3. Small temples are now seldom used for worship as most of the present generation of owners have migrated out of the Pakka Mohalla and are no more associated with sacred rituals. These now act as a symbol of property and allow new communities to establish (break in common-unity). Heterogeneity in common-unities results in weak bondage, if not incompatibility, between 

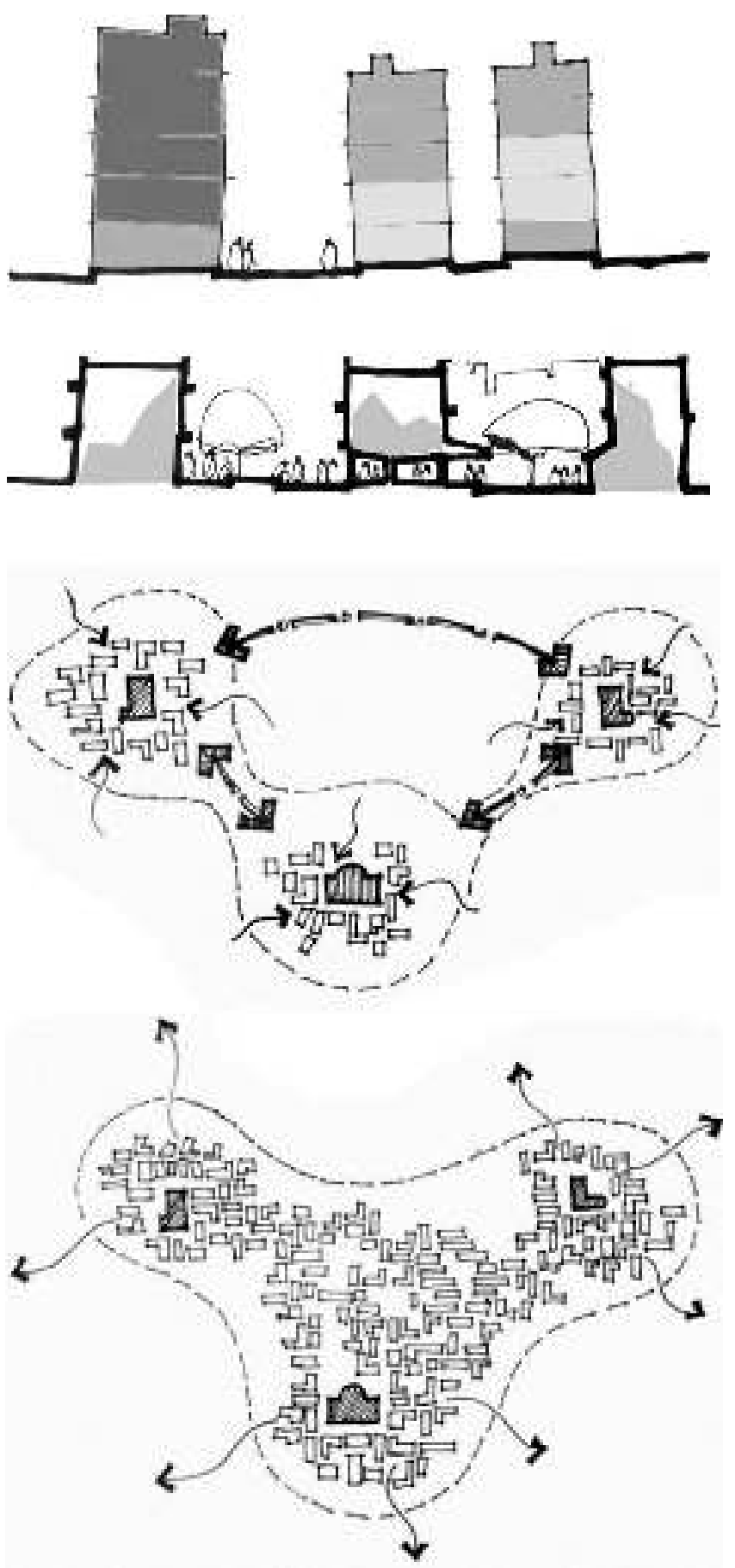

Figure 26: Mixed-ness in community (Source: Author).

Modernity: A Way of Urbanism

-- Banaras In Indigenous TransFormations

Figure 27: Homogeneous communities (Source: Author). 
residents. This may result in depreciation in religiosity and unjustified encroachment of public and semi-public spaces as no mutual understanding persists within the residents for issues such as like easement of light, ventilation and access for others along with strange urban behavior (Fig. 24).

3.1.4. Sacred communities get gentrified by occurances such as displacement of less income groups. This results in social inequality and economic polarity in the originally economically homogenous built environment (Fig. 25).

3.1.5. 'Lonely Planet' is the new Bible for the transformed homogeneous communities to follow and exhibit. The virtual contestation in the articles leads to transformation of built and social fabric in the real world (Fig. 26). The diversity in the community will be intra-homogenized if all communities develop under similar larger forces of development. If guided and controlled, it may lead to a stronger agent of preserving the Banarsi culture (Fig. 27).

3.1.6. The Pakka Mohalla evolves as a heritage and cultural district. As per the development guidelines, within the heritage zone, relatively fewer residential (other than those who provide services to sustain economic activities) units exist and most of the structures have been transformed into culture, heritage and tourist oriented guest houses and hotels. These contest the Ghats and westernize the definition of public space with open cafés and niches. Larger live-work distances become less economical and require better infrastructure. In the flow of unconscious economic oriented development, there might be a condition in which tourist accommodations and services provided are much more than required at a particular time, mainly during off-season. This may lead to economic breakdown, which will have implication on quality and redundancy of function and, hence the urban form (Fig. 28).

3.1.7. Sacrality is concentrated only on festivals and events, and mostly eradicated from day to day life. But, these events, which witness heightened religiosity, have become major tourist and economic attractions. The Pakka Mohalla transforms itself totally for such events. The day to day religious activities are limited to private domestic units. Due to most residents becoming less religious, materialistic and adopting a more modern urban lifestyle, the day to day footfall to the temple has reduced, which has also transformed the activity pattern around such nodes. The robustness of spaces has been enhanced as per the needs of the event.

3.1.8. Due to the economic benefits, the extent of Ghats (towards a riverfront development) permeate beyond the sacred cosmic boundary, i.e., the Raj Ghat in north and the Assi Ghat in south of Varanasi Metropolitan Area. It may help in polarizing tourist and pilgrims, where pilgrims can be concentrated to core Ghat 


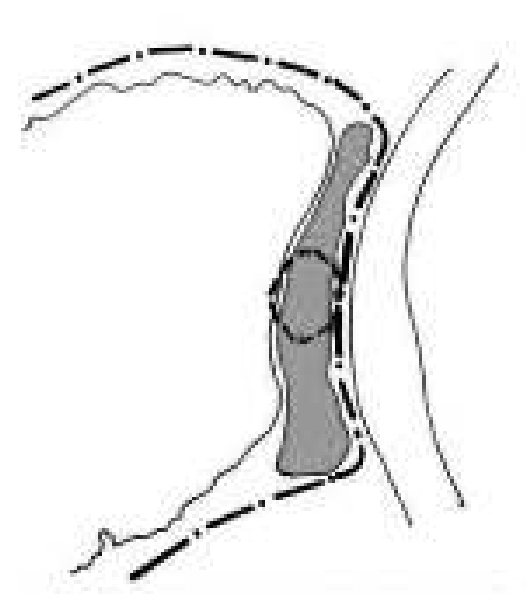

Mbed land use

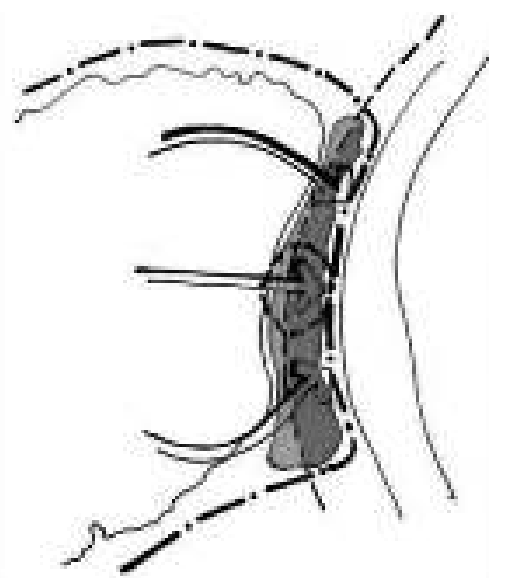

Larger live-work relationship

Modernity: A Way of Urbanism

-- Banaras In Indigenous Trans-

Formations

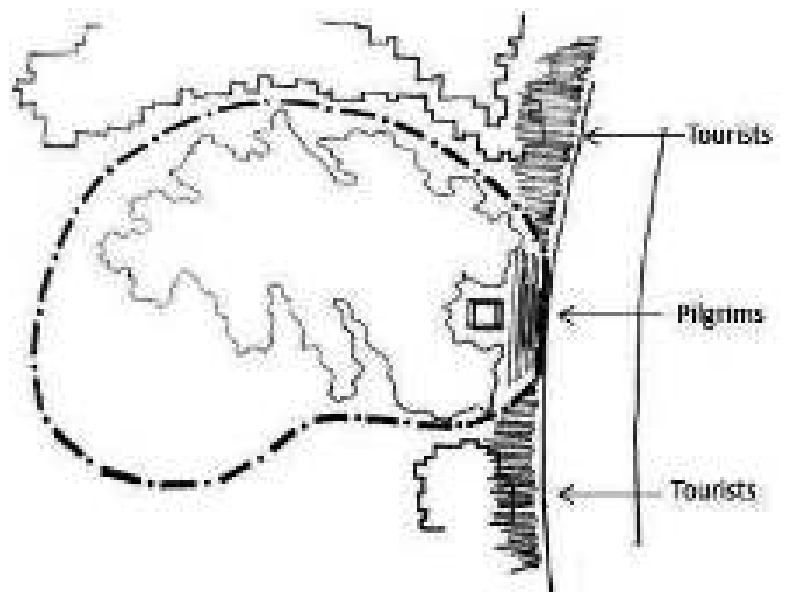

Figure 28 (above): Core Heritage Zone and Livework Relationship (Source: Author).

Figure 29 (Left):

Decentralizing visitors; tourists and pilgrims (Source: Author)

zone and visitors, may use the peripheral Ghat zones for recreation based on the indigenously traditional culture of Bana-ras coupled with the comfort of modern amenities. This will help in maintaining sacrality of Banaras (Fig. 29).

\subsection{Way Forward: The Actions}

Urban Design Recommendations: The sacredness and traditions, which need to be carried forward to sustain the identity of Banaras, include:

- Sacred Activity Patterns: Religious activities in public spaces, local and tourist oriented commerce that allows sustenance of indigenous communities responsible for the generation of such activities. 
Dev, A

- Sacred Movement Network: Procession routes (from funeral processions to pilgrimage circuits) and Ghats as a part of the movement system.

- Sacred Morphological Character: Ghats, temples, ashrams, shikhars and turrets, courtyard typology with temples and family gathering spaces -together leading to an area of fine grain and even texture.

- Sacred Functional Nodes: Religious functional nodes (Temples and 'Muths'), pilgrimage functional nodes (community centers and 'dharamshalas'), cultural nodes (art and craft centers, literature centers and yoga centers)

The deliberate act of passing cultural heritage from the present to the future is known as preservation. Cultural heritage is unique and irreplaceable, which places the responsibility of preservation on the current generation. The conservation plan should aim at ensuring harmonious relationship between the historic urban areas and the town as a whole.

3.2.1 Local Area Plans: These must be developed for a group of Mohallas (if not the Mohalla itself) as a social entity (and not according to Wards) to maintain or regain the heterogeneity of communities and associated urbanism (Fig. 30). The envisioning period for each Local Area Plan might be different depending on the pace of transformation contextual to that particular Mohalla. The plan must comment on:

- Control over the spread of commercial activity.

- Enhancement of the generic indigenous identity of each Mohalla.

- The Mohalla Committee would empower people to take decisions regarding work that affects them directly. Government schools, Anganwadis, primary hospitals and dispensaries will be supervised by the Mohalla Committees as adaptation of these areas to contemporary life requires careful installation or improvement of public service facilities. In the case of sacred Mohallas, the stakeholders, such as pandits, sadhus, ashrams, even commercial stakeholders, play a pivotal role. In order to encourage residents' participation and involvement, a general information program, contextually themed documentations, sensitive structure plans, etc. should be set up for all residents, beginning from children of school age.

3.2.2. Functional and Activity Control: Activities are generated through local communities and, hence, must be preserved. As per the speculated scenarios, the functional sprawl needs to be guided and controlled in such a way that the character of the Pakka Mohalla (both tangible and intangible) and economic growth are maintained in equilibrium. The functional containment will also lead to control over the expansion of activity. Some of the remedies can be: 

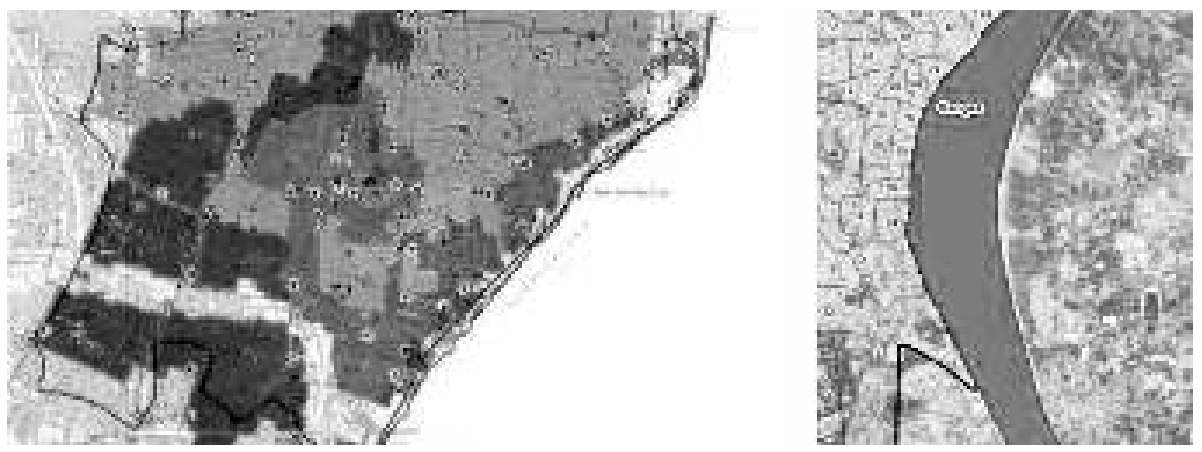

Modernity: A Way of Urbanism

-- Banaras In Indigenous Trans-

Formations
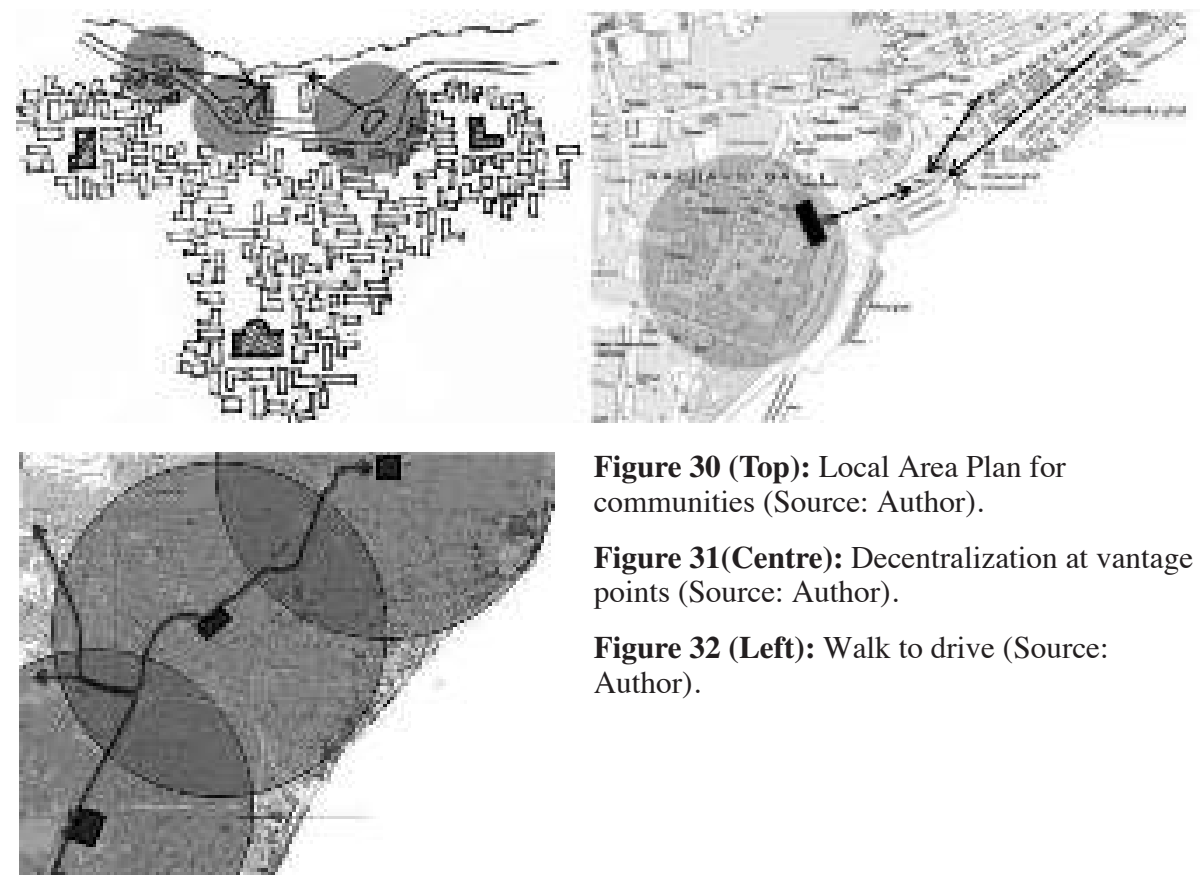

Figure 30 (Top): Local Area Plan for communities (Source: Author).

Figure 31(Centre): Decentralization at vantage points (Source: Author).

Figure 32 (Left): Walk to drive (Source: Author).

- Mixed land-use must be permissible to enable easier live-work relationship (retaining indigenous communities), indigenous character, increasing economic activities, stronger neighborhood character, enhanced vitality, street safety and variety in density patterns.

- Functional and form-based limitations must be introduced for a particular quantity and quality of hotels and guesthouses. Activity sprawl around the vantage points must be guided and decentralized wherever needed, particularly at the sacred nodes like Manikernika Ghat and Dashashwamedha Ghat (Fig. 31). 


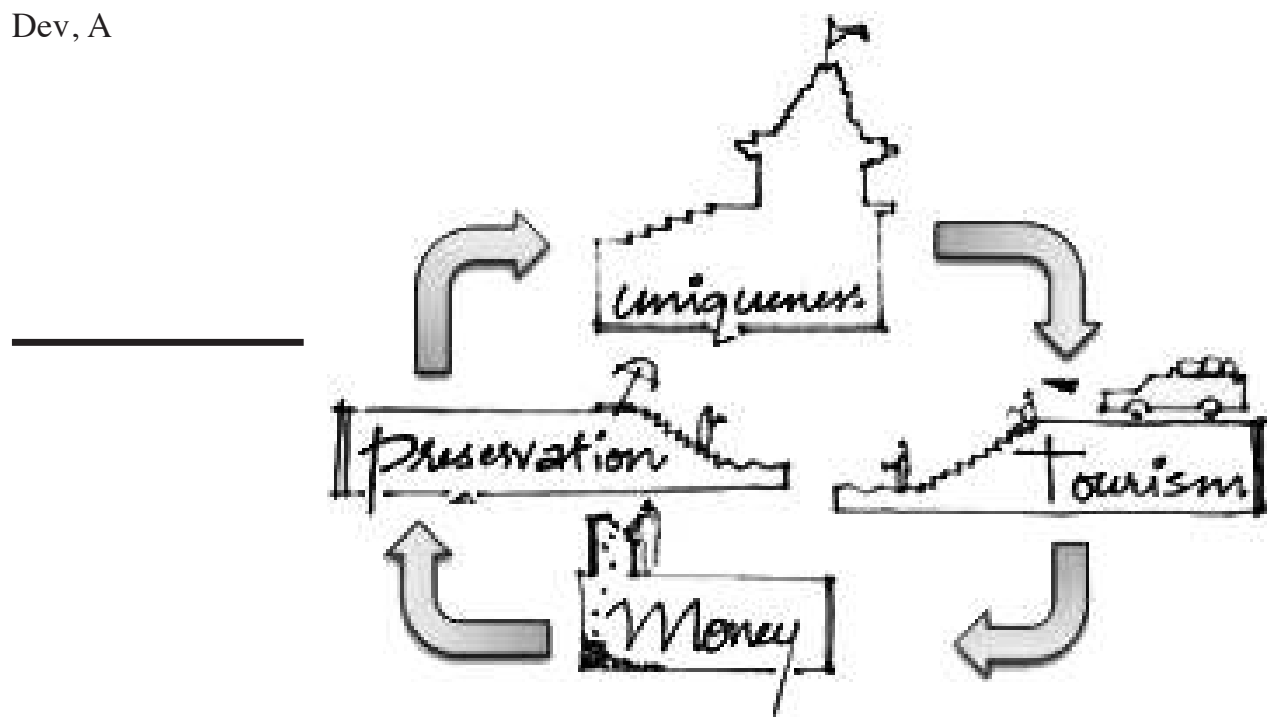

Figure 33: Tourism as catalyst (Source: Author).

- Licensing of boating activity to be regulated to maintain sacred bathing activities and control unauthorized expansion due to the economic benefits.

3.2.3. Movement Network: Movement not only defines the linkages between functional nodes but also manipulates patterns of activities. It is critical in sacred towns so as to maintain sacred movement network, such as procession routes (funeral processions to pilgrimage routes) and the movement patterns on the Ghats. Some of the connections can be designed for vehicular traffic inside a historic town. This must be controlled and parking areas must be planned so that they do not damage the historic fabric or its environment (Fig. 32). Vehicles (other than service vehicles) must not penetrate the historic town, but should only have access to common parking nodes (walk to drive, and not drive to walk). The movement corridors may include psycho-visual strategies such as "Movement towards a goal", "Rhythmic intervals by interruptions, elongations and beautification", "Continuity", "Building visual tension" and the final goal or the climax where tension is relieved -- the Ghats or temples.

3.2.4. Typological Evolution and Morphological Character (Visual Design): Both the sacred Mohallas and the traditional residential fabric must see a typological change under the transforming social, economic and policy-based causes while striving to respond to the context. Such transformations may include:

- Building byelaws that promote courtyard typology with multi-unit housing as apartment typology (with separate kitchen and washrooms) with semi- 


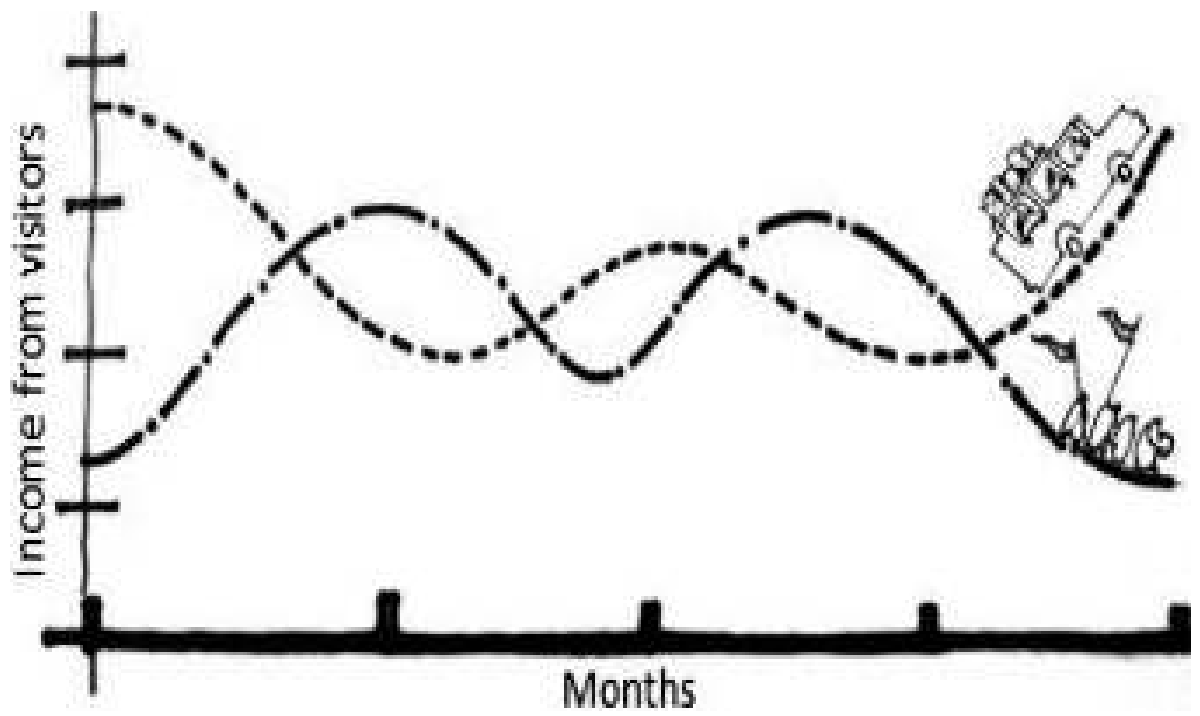

Modernity: A Way of Urbanism

-- Banaras In Indigenous Trans-

Formations

Figure 34: Temporality and visitors pattern (Source: Author).

private public space in the center with a temple or a socializing space. Benefits such as tax incentives must be provided to the residents in return of maintaining the historic character of their residences and temples.

- Ashrams to have a public front (which may include community level temples, guest houses, commercial or sacred function (only tourism based commerce, if part of decentralizing strategy) and, core inner areas for sacred function with limited public permeability.

- Whenever it is necessary to construct new buildings or adapt existing ones, the existing spatial layout should be respected, especially in terms of scale and lot size (amalgamation of plot may be allowed only for social or religious purpose with FAR controls as per different contexts.

3.2.5. Promotion of Tourism as Catalyst: The major cause of tourism and pilgrimage in a sacred city is the uniqueness that its urbanism offers. This must give rise to the protection, preservation and promotion of the city's religious, cultural and economic values (Fig. 33). A few steps towards its execution can be:

- Guest houses must promote indigenous lifestyle by retaining indigenous architecture. City level festivals and events must be organized, which may temporarily decentralize tourist footfall from pilgrimage, being at the same location (Fig. 34). This will generate economy through the year while not compromising the sacrality. 
Dev, A

- To safeguard the uniqueness, prohibited and regulated areas as suggested by NMA may be challenged as the boundary of regulations may vary with the local influences of both tangible and intangible factors.

\subsection{Beyond Existing Formations: A Conclusion}

Modernity, as a process and not as an output, is a derivative of transformation. Transformations vary for different aspirations of its producers. Aspirations are negotiations between the needs and desires and what can actually be achieved. During this process, the sacredness also alters under the agents of Modernity that are essential to preserve and promote the essence of the sacred cities. The uniqueness is the reason, why indigenous Modernity is different for different contexts. It is a harmonious adaptation to contemporary life. The cause to such transformations can be global but the effects will always be a derivative of indigenous reactions with Modernity. As applied specifically to sacred cities, which are grounded in tradition and have a responsibility of carrying it forward, the reaction with global Modernity results in indigenous Sacred Modernities.

\section{REFERENCES}

[1] ALSAYYAD, NEZAR (ed.) (2001) Consuming Tradition - Manufacturing Heritage: Global Norms and Urban Forms in the Age of Tourism. New York: Routledge.

[2] APPADURAI, ARJUN (1996) Modernity At Large: Cultural Dimensions of Globalization (Public Worlds, Vol. 1). Minneapolis: University of Minnesota Press.

[3] BENTLEY, I., ALCOCK, A. et al (1985) Responsive Environments: A Manual for Designers. Burlington, USA: Elsevier.

[4] CALLEWAERT, W. M. AND SCHILDER, R. (2000) Banaras: Vision of a Living Ancient Tradition. New Delhi: Hemkunt Publishers Private Limited.

[5] ECK, DIANA L. (1982) Banaras, City of Light. New York: Columbia University Press.

[6] ECK, DIANA L. (2011) India, A Sacred Geography. New York: Harmony Books.

[7] FREITAG, SANDRIA B.(ed.) (1992) Culture and Power in Banaras: Community, Performance, and Environment, 1800-1980. Berkeley: University of California Press.

[8] GESLER, W. M. AND PIERCE, M. (2000) Hindu Varanasi. In The Geographical Review, 90 (2), 222-237

[9] GOI (1999) A Pilgrimage to Kashi: Banaras Varanasi, Kashi : History, Mythology, and Culture of the Strangest and Most Fascinating City in India. Varanasi: Indica Books. 
[10] HARVEY, D. (1989) The Condition of Postmodernity: An Enquiry Into the Origins of Cultural Change, New Jersey: Blackwell.

[11] HOSAGRAHAR, JYOTI (2005) Indigenous Modernities: Negotiating Architecture and Urbanism. New York: Routledge.

[12] ISAACS, ALICK (2005) Jerusalem 3000, Lecture 10 - Modernity Comes to Jerusalem. Available from: http://www.jewishagency.org/jerusalem/ content/23682. [Accessed: 30 April 2016]

[13] MICHELL, G., SINGH, RANA P. B., ARNI, CLARE (2005) Banaras, the city revealed. Mumbai: Marg Publications on behalf of the National Centre for the Performing Arts

[14] MISHRA, KAMALA PRASAD (1975) Banaras in transition 1738-1795: A socio economic study. Varanasi: Munshiram Manoharlal Publishers.

[15] SHACKLEY, MYRA (2001) Managing Sacred Sites: Service provision and Visitor Experience. London and New York: Continuum.

[16] SHRIVASTAVA, S.K. (ed.) (1976) Tradition and Modernization: Process of Continuity and Change in India. Allahabad: Indian International Publication.

[17] SINGH, RANA P. B., SINGH, RAVI S. AND RANA, PRAVIN S. (2002) Sacred Geography of the Goddesses in Kashi (Varanasi). In Journal of Geography, Vol 3, (Gauhati University, Guwahati, AS, India), October: p. 11-35.

[18] SINGH, RANA P.B. (1993) Cosmic Layout of the Hindu Sacred City, Varanasi (Benares). In Architecture \& Comportement / Architecture \& Behaviour. 9(2). p. 239-250

[19] SINGH, RANA P.B. (ed.) (1993) Banaras: cosmic order, sacred city, hindu traditions. Varanasi: Tara Book Agency.

[20] SMITH, BARDWELL L. and REYNOLDS, HOLLY BAKER (eds.) (1987) The City as a Sacred Centre: Essays on Six Asian Contexts. New York: E J BRILL.

[21] SRIVASTAVA, URVASHI, (2002), Remapping Banaras: A city in continuum. In Architecture plus Design: A Journal of Indian Architecture, Vol. XIX No.1 JanFeb 2002. Available from: https://indiaheritagehub.org/2011/12/17/remappingbanaras-a-city-in-continuum/ [Accessed: 15 March 2016]
Modernity: A Way of Urbanism

-- Banaras In Indigenous Trans-

Formations 